\title{
Plastic Surgery in Ayurveda
}

\author{
*Dnyaneshwar kantaram Jadhav \\ Department of Ayurved Medicine, Director of Nakshatra Ayurved clinic \& Research center, India
}

Submission: March 31, 2017; Published: April 20, 2017

*Corresponding author: Dnyaneshwar kantaram Jadhav, Department of Ayurved Medicine, Director of Nakshatra Ayurved clinic \& Research center, Mumbai, India, Email: dj85015@gmail.com

Abstract

From ancient Indian surgery, it has been observed that various operations successfully performed in those days also. In ancient period Acharya were doing surgery in Ayurveda. Sushrut was the first and famous surgeon of ancient science. There are so many examples and descriptions of surgery available in Ayurvedic Samhita. Sushrut has described plastic surgery like Nasa-sandhan (Rhinoplasty), Karna-sandhan (Auroplasty) and Oshta-sandhan (lipoplasty). Contribution of ancient Indian surgery in the field of plastic operation cannot be over-estimated.

It's true that in old days one of Royal punishment was to cut way ear-lobe, nose etc. Indian surgeon correcting such deformity by shifting the skin flap to reform the nose and ear. They had plenty of opportunity to do Rhinoplasty which was first to be done in this country and itself made Indian surgery unique. They also appreciated the importance of proper wound healing for successful plastic surgery operation. It is common man's thinking that there is no surgical treatment for disease in the science of Ayurved. After the turn over the pages of sushrut Samhita, one will understand that sushrut has laid done the basic concept of the present surgery. The present article is an attempt to highlighting on reference of ancient plastic surgery in Ayurveda.

Keywords: Plastic surgery, Sandhan Karma, Ayurveda, Sushrut.

\section{Introduction}

Ayurved science of life which is divided into 8 branches. Shalya (surgery) is one of the branches of Ashtanag Ayurved [1]. In ancient time Ayurveda was at top point of mountain but in between there was long period of slavery and Indian become depend country on British government. This is period of decline period of Ayurved and now common man's thinking that there is no surgical treatment for disease in the science of ayuvred. It takes a beet troubles to turn over the pages of sushrut Samhita, one will find that sushrut has laid done the basic concept of the present surgery. Sushruta is considering as father of modern surgery, because of his logical approach prudent and Clare view and marvellous presentation which is time tested. From ancient Indian surgery, it has been observed that various operations successfully performed in those days also. The various surgical procedures were divided in chedya, bhedya and vedhya [2]. Chedankarma was performed in those disease were suppuration is absent, swelling is herd and immovable or in those diseases where gangrene develops. The same procedure is still being adopted in modern science. Hand is best instrument for surgery [3].

\section{Materials and Methods}

For the present review detailed literary study is performed. The Detail content of and references are analysed from available text. Principal texts referred are Sushrutasamhita and some Vedas. Also relevant references are taken from other Research articles available from internet.

\section{Meaning of Plastic Surgery}

Plastic surgery is a surgical speciality involving the restoration, reconstruction, or alternation of human body. It includes cosmetic or aesthetical surgery, hand surgery, microsurgery and treatment of burns [4].

\section{History of Plastic Surgery}

The oldest surgical references found in Ancient Egyptian medical text [5]. This Reconstructive surgery technique was being carried out in India. Sushruta was a physician that made important contributions to the field of plastic and cataract surgery in 6th century BC. The medical works of both Sushruta and Charak originally in Sanskrit were translated into the Arabic language during the Abbasid Caliphate in 750 AD [6]. The Arabic translations made their way into Europe via intermediaries. After that surgical technique of sushruta is followed in Italy.

British physicians travelled to India to see rhinoplasties being performed by native methods. They Reported on Indian rhinoplasty performed by a Kumharvaidya which was published in the Gentleman's Magazine by 1794 [7]. Joseph Constantine 
Carpue spent 20 years in India studying local plastic surgery methods. Carpue performed the first major surgery in the Western world by 1815 [8]. Instruments described in the Sushruta Samhita were further modified in the Western world. The Roman scholar Aulus Cornelius Celsus recorded surgical techniques, including plastic surgery, in the first century AD. The Romans also performed plastic cosmetic surgery. They were able to perform simple techniques, such as repairing damaged ears, from around the 1 st century BC.

\section{References of Plastic Surgery in Vedas [9]}

Description of Sandhan karma found in ancient times. During Vedik period science of Sandhan karma is very well developed. Reference of Magical operative surgery of Ashwinikumaras mentioned in vedas.

In anger Lord Shiva cuts the head of Ganesha, later on which is replaced with head of elephant. After that event shree Ganesha is known as "Gajanana" This is best example of transplantation which is well listen since childhood from our mothers and grandmother in stories.

Bispala is wife of king Khela. She lost her leg in war. Ashwinikumaras was transplanted her leg with an iron leg [10]. The lost part of body of Rishi Atriwas was re-joined by Ashwinikumaras. The body of Acharya Shyaba was cut into three parts. Ashwinikumars immediately re-joined all parts and give him life [11]. Beside the Rigved, Padampuran also have written examples of reconstructive plastic surgery [12]. Bhairav cut the head of Brahma and Dadhichi. Ashwinikumaras re-joined their head. They also transplanted the head of Yahnya. Dadhyancha was the master of Madhu Vidya. Ashwinikumaras showed them interest in learning of Madhu Vidya. So they cut head of Dadyyancha and kept separate. Then they transplant the head of horse to the body of Dadhyancha and learnt Madhu Vidya from them. After learning Madhu Vidya, they transplanted his own head [13]. Dakshya cut head and trunk of Chyavan. Ashwinikumaras performed the first plastic operation to join them [14].

According to Upanishad, Ashwinikumaras also operated and repaired the excised head of Yagyana by Rudra. Ashwinikumaras were doing both homo and hetero transplantations at that time.

\section{Plastic Surgery in Ayurved}

Sushrut has described plastic surgery. In plastic surgery particular Nasa-sandhan (Rhinoplasty), Karna-sandhan (Auroplasty) and Oshta-sandhan (lipoplasty) are mentioned in Ayurved. Contribution of ancient Indian surgery in the field of plastic operation cannot be over-estimated. It's true that in old days one of Royal punishment was to cut way ear-lobe, nose etc [15]. Indian surgeon has applied their injurious technique for correcting such deformity by shifting the skin flap to reform the nose and ear. They had plenty of opportunity to do rhinoplasty which was first to be done in any country and itself made Indian surgery unique. They also appreciated the importance of proper wound healing for successful plastic surgery operation.

Sushruta has described 15 methods of Karna-sandhan (Auroplasty) repairs of the several ear-lopes [16] (Table 1).

Table 1: Showing Techniques of karna-sandhan-vidhi (Rhinoplasty).

\begin{tabular}{|c|c|c|c|c|c|}
\hline \multicolumn{5}{|c|}{ Techniques of karna-sandhan-vidhi (Rhinoplasty) } \\
\hline 1 & $\begin{array}{c}\text { Nemisand- } \\
\text { hanaka }\end{array}$ & 6 & Nirvedham & 11 & Hinakarna \\
\hline 2 & Utpalbheda & 7 & Vyayojinam & 12 & Vallikarna \\
\hline 3 & Valluraka & 8 & $\begin{array}{c}\text { Kapatsandi- } \\
\text { nam }\end{array}$ & 13 & Yashtikarna \\
\hline 4 & Asangima & 9 & $\begin{array}{c}\text { Ard- } \\
\text { hakapatsan- } \\
\text { dinam }\end{array}$ & 14 & kakoshataka \\
\hline 5 & Aaharya & 10 & Sankhipta & 15 & gandakarna \\
\hline
\end{tabular}

Sandhanarthajivitamansa (pedicled skin flap) [17]:

If skin flaps unavailable from ear during Auroplasty than for Sandhanprakriya (plastic surgery) than it can take from Gandapradesha (living flap connected as base of cheek).

\section{karnasandha-vidhi (Auroplasty)}

Mahrshi Sushruta described the detail procedure of karnasandha-vidhi (Auroplasty) in his sushrutasamhita [18].

\section{Nasa-sandhanvidhi (Rhinoplasty)}

Sushruta mentioned Nasa-sandhanvidhi (Rhinoplasty) for nose either lost by disease or by trauma/accident. Description of Nasa-sandhanvidhi (Rhinoplasty) is available in sushrutsamhita. The original method of Nasa-sandhan (Rhinoplasty) reveals that first of all the leaf of creeper should be collected. It should be adequate in length and breath, to cover the entire severed portion. Then a patch of living hash of the size of previously trimmed leaf should be excised with an attached pedicals. So the excised skin flap is maintained by its vascularity. Thus skin flap is than over lapped to severe portion and stitched. The insertion of kamalnaal into nostril to vacillated respiration and to maintain the suture [19].

\section{Oshthasandhan-vidhi (lipoplasty)}

Maharshisushruta mentioned sandhan-vidhi of china oshtha (lipoplasty) for khandoshta (harelip) [20]. sandhan-vidhi of china oshtha (lipoplasty) is same as Nasa-sandhanvidhi (Rhinoplasty). The only difference is that in lip surgery there is no use of stem of Erandanaala. In Sushruta it is also mentioned that, Vaidya who get skilled in these reconstructive surgery, become Rajvaidya i.e. who can treat the king. So From above review it can be said that, sushruta was the original plastic surgeon not only in India but also in the world.

\section{Conclusion}

In Ayurvedic achrya Sushrut has described plastic surgery. Nasa-sandhan (Rhinoplasty), Karna-sandhan (Auroplasty) and 
Oshta-sandhan (lipoplasty) and many more sandhan (plastic surgery) are mentioned in Ayurved. Contribution of ancient Indian surgery in the field of plastic operation cannot be overestimated. All of this it made Indian surgery unique.

\section{References}

1. Anand Ram Sharma (2010) 'susrutavimarsini' Hindi commentary. $\left(1^{\text {st }}\right.$ edn), Susrutasamhita, maharshisusruta sutra-stan vedottpattiadhyaya, Chukhambhaprakashan, Varanasi India 1(6): 4.

2. Anand Ram Sharma (2010) 'susrutavimarsini' Hindi commentary. $\left(1^{\text {st }}\right.$ edn), Susrutasamhita, maharshisusruta, sutra-stan shastravchriniyaadhyaya, Chukhambhaprakashan, Varanasi, India 8(4): 65.

3. Anand Ram Sharma (2010) 'susrutavimarsini' Hindi commentary. ( $1^{\text {st }}$ edn), Susrutasamhita, maharshisusruta. sutra-stan yantravidhiadhyaya, Chukhambhaprakashan, Varanasi, India 7(3): 57.

4. https://en.m.wikipedia.org/wiki/plastic_surgery

5. Mazzola, Ricardo F, Mazzola, Isabella C. Plastic Surgery: Principles. Elsevier Health Sciences, Netherlands, Europe, p. 11-12.

6. Lock, Stephen (2001) The Oxford Illustrated Companion to Medicine. Oxford University Press, USA, pp. 607.

7. Lock, Stephen (2001) The Oxford Illustrated Companion to Medicine. Oxford University Press, USA, pp. 651.

8. Lock, Stephen (2001) The Oxford Illustrated Companion to Medicine. Oxford University Press. USA, pp. 652

9. Ahuja Deepak, Mishra Vandana (2014) Plastic and reconstructive surgery in Ayurved. IAMJ 2(1): 83.
10. http://www.sacred-texts.com/hin/rvsan/rvi01.htm

11. http://www.sacred-texts.com/hin/rigveda/rvi01.htm

12.https://en.wikipedia.org/wiki/Padma_Purana

13. http://www.sacred-texts.com/hin/rigveda/

14. http://www.sacred-texts.com/hin/rvsan/rvi01.htm

15. Damayanti Doongaji (1986) Crime and punishment in ancient Hindu society. Ajanta publications, Delhi, India, pp. 149.

16. Anand Ram Sharma (2010) 'susrutavimarsini' Hindi commentary. ( $1^{\text {st }}$ Edn), Susrutasamhita, maharshisusruta, sutra-stan, karnavhyadbandhanvidhi-adhyaya, Chukhambhaprakashan, Varanasi, India 16(9): 134.

17. Anand Ram Sharma (2010) 'susrutavimarsini' Hindi commentary. ( $1^{\text {st }}$ Edn), Susrutasamhita, maharshisusruta, sutra-stan, karnavhyadbandhanvidhi-adhyaya, Chukhambhaprakashan, Varanasi 16(14): 136.

18. Anand Ram Sharma (2010) edited with 'susrutavimarsini' Hindi commentary. ( $\left.1^{\text {st }} \mathrm{Edn}\right)$, Susrutasamhita, maharshisusruta, sutra-stan karnavhyadbandhanvidhi-adhyaya, Chukhambhaprakashan, Varanasi, India 16(15): 136.

19. Anand Ram Sharma (2010) 'susrutavimarsini' Hindi commentary. $\left(1^{\text {st }}\right.$ Edn), Susrutasamhita, maharshisusruta, sutra-stan karnavhyadbandhanvidhi-adhyaya, Chukhambhaprakashan, Varanasi, India 16(28-32): 141.

20. Anant Ram Sharma (2010) 'susrutavimarsini' Hindi commentary. ( $1^{\text {st }}$ Edn), Susrutasamhita, maharshisusruta, sutra-stan, karnavhyadbandhanvidhi-adhyaya, Chukhambhaprakashan, Varanasi, India 16(23): 141.

\begin{tabular}{l} 
Your next submission with Juniper Publishers \\
will reach you the below assets \\
- Quality Editorial service \\
- Swift Peer Review \\
- Reprints availability \\
- E-prints Service \\
- Manuscript Podcast for convenient understanding \\
- Global attainment for your research \\
- Manuscript accessibility in different formats \\
( Pdf, E-pub, Full Text, Audio) \\
- Unceasing customer service \\
Track the below URL for one-step submission \\
https://juniperpublishers.com/online-submission.php \\
\hline
\end{tabular}

